\title{
Capsule Commentary on Salyers et al., The Relationship Between Professional Burnout and Quality and Safety in Health Care: A Meta-Analysis
}

\author{
Shana F Sandberg, PhD \\ Quality, Measurement, and Research Group, National Committee for Quality Assurance, Washington, DC, USA.
}

JGenInternMed32(4):474

DOI: $10.1007 / \mathrm{s} 11606-017-3998-\mathrm{x}$

(c) Society of General Internal Medicine 2017

$\mathrm{T}$ his meta-analysis by Salyers et al. ${ }^{1}$ investigated the relationship between health care provider burnout and the quality and safety of care. Drawing upon 82 studies published between 1982 and 2015, the authors found statistically significant negative relationships between burnout and quality (63 studies; $r=-0.26$ ) and safety (40 studies; $r=-0.23$ ) of care. These results suggest that greater burnout among health care providers is associated with poorer-quality health care and decreased safety for patients. The authors conclude that health care provider burnout is an important area for future research, and that burnout can be a target for interventions that could have benefits for both providers and patients.

As with any meta-analysis, the validity of the authors' results depends upon the rigor of the individual studies included in the analysis. The authors point out that the individual studies included were predominantly cross-sectional rather than longitudinal. This is a common feature of studies in health care settings, but it makes it difficult to draw conclusions about any causal relationship (for example, does burnout over time reduce a provider's quality of care, or are providers of lowquality care more likely to suffer from burnout?). The included studies were also predominantly based on self-reports, meaning that they were based on patient or provider perceptions of quality or safety rather than on calculations derived from more objective metrics, such as the number of safety incidents or performance based on quality measures with clear specifications. These limitations are not unique to this meta-analysis, but they do underscore the need for more rigorous individual studies of the relationship between provider burnout and quality and/or safety going forward.
Despite the limitations, however, this meta-analysis makes a very important contribution to the field. Reports of burnout symptoms among large proportions of U.S. physicians relative to the general U.S. population ${ }^{2}$ have spurred national discussions about provider well-being ${ }^{3}$ and its impact on patient care. ${ }^{4}$ As quality becomes an increasingly important metric upon which reimbursement relies, ${ }^{5}$ it is incumbent upon providers to better understand the relationship between provider burnout and the quality and safety of care.

Corresponding Author: Shana F Sandberg, PhD; Quality, Measurement, and Research GroupNational Committee for Quality Assurance, Washington, DC, USA (e-mail: sandberg@ncqa.org).

\section{Compliance with Ethical Standards:}

Conflict of Interest: The author has no conflicts of interest with this article.

\section{REFERENCES}

1. Salyers MP, Bonfils KA, Luther L, Firmin RL, White DA, Adams EL, Rollins AL. The relationship between professional burnout and quality and safety in health care: a meta-analysis. J Gen Intern Med. doi:10.1007/ s11606-016-3886-9.

2. Shanafelt TD, Boone S, Tan L, et al. Burnout and satisfaction with worklife balance among US physicians relative to the general US population. Arch Intern Med. 2012;172(18):1377-1385.

3. Bodenheimber T, Sinsky C. From triple to quadruple aim: care of the patient requires care of the provider. Ann Fam Med. 2014;12(6):573576.

4. Friedberg MW, Chen PG, Van Busum KR, Aunon AM, Pham C, Caloyeras JP, Mattke S, Pitchforth E, Quigley DD, Brook RH, Crosson FJ, Tutty M. Factors affecting physician professional satisfaction and their implications for patient care, health systems, and health policy. Santa Monica, CA: RAND Corporation; 2013. Available at: http://www.rand.org/ pubs/research_reports/RR439.html; accessed 12/30/2016.

5. Centers for Medicare \& Medicaid Services (CMS), HHS. Medicare Program; Merit-Based Incentive Payment System (MIPS) and Alternative Payment Model (APM) Incentive Under the Physician Fee Schedule, and Criteria for Physician-Focused Payment Models. Final rule with comment period. Fed Regist. 2016;81(214):77008-831. 